Japanese Journal of Transfusion Medicine, Vol. 44. No. 3 44(3) : 430-432, 1998

輸血問題検討部会 平成 9 年 5 月23日（金）

GVHD と放射線照射

\title{
Introduction
}

\section{GVHD の現況・その臨床と基礎}

\author{
京都大学輸血部 \\ 伊 藤 和 彦
}

1.はじめに

昨年の 4 月に厚生省は輸血後 GVHD に関する緊急 安全性情報 No. 1を出した。同種血輸血によって致命 的な GVHD が起きることがあるので, 輸血の適応を 慎重に決定すること, 血液製剤に放射線照射を行うこ と，自己血輸血を実施すること，を骨子とする．同年 12月になって, 日本赤十字社中央血液センターから出 された緊急安全性情報で, 4 月以降に輸血後 GVHD 7 症例の報告が医療機関からあったことが示された。 一方, 日本輸血学会では, 「輸血によるGVHD 予防の

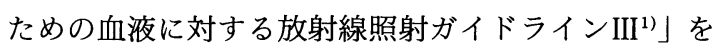
12月に出して対応した.

厚生省の緊急安全性情報が出された後も輸血後 GVHD 症例が続出していることは,一部の病院を除い ては，血液に放射線照射をする体制が整っていないこ とを物語っている。緊急な対応, 対策が必要である.

この時期に, 輸血問題検討部会で「GVHD と放射線 照射」が取り上げられた理由は, いままで行われて来 た対応，対策を再検討して，改善の道を探るためと考 える。

\section{2. 輸血後 GVHD の発症機構と頻度}

血液には増殖可能な単核球（リンパ球，単球，造血 幹細胞）が含まれているので, 同種血輸血は単核球移 植である，通常の輸血では単核球は拒絶される。拒絶 能力のない免疫不全患者では, GVHD が高頻度に発症 する.一方, 免疫不全でない受血者でも, ドナーと受 血者の HLA 型が特異な組み合わせで，ドナーから見 て, 一方向適合 (HLA one-way match) の場合には GVHD が発症する危険がある.この組み合わせは非血 縁者間の輸血では約 $1 / 1,000$ の頻度で起きる.親子間で は約 $1 / 100$ の頻度である. 頻度がこのように高いのは, 日本人が人種的均一性が高いためである。

日本人での実際の輸血後 GVHD 発症頻度はどのく らいであろうか. 現在では一部で血液放射線照射が行
われているので，発症頻度は下がって来ている．照射 開始前の時代は, 本症についての知識が医師に無かっ たために, 確実な診断がされていない. 従って, 推測 值になるが年間100〜200症例であろうか. 平成 7 年度 に全国の赤十字血液センターから約 300 万バッグの全 血製剤, 赤血球製剤および血小板製剤が供給された。 これから推測すると，1〜2/3万回輸血，の頻度で輸血 後 GVHD が発症している. HLA 一方向適合の組み合 わせ頻度とGVHD 発症頻度に比べて発症頻度は低 い.これはいかなる要因によって左右されているのか, 明らかでない。

\section{3. $\mathbf{T}$ cell-mediated GVHD}

輸血後 GVHD ではドナーの T リンパ球も B リン パ球も宿主に生着すると考えられるが, 症状は T cellmediated GVHD で, 急性の経過を取る. 当該患者か らドナーの T リンパ球および $\mathrm{B}$ リンパ球が継代培養 されて，宿主の抗原を標的にすることが報告されてい る2). しかし，抗体産生を介するB cell-mediated GVHD は, 発症により長い時間がかかり, さらに T cell-mediated GVHD の症状が強いので，その所見は 観察されにくいと推測される.

\section{B cell-mediated GVHD}

骨髄移植の慢性 GVHD では, B cell-mediated GVHD の関与が知られている.一方, 実質臟器移植が 普及しつつあり, GVHD が副作用として問題になって 来た。臟器に含まれたドナーリンパ球が宿主に移入さ れる.この passenger lymphocytesには Tリンパ球も Bリンパ球も含まれている筈であるが, $\mathrm{T}$ cellmediated GVHD ょりもB cell-mediated GVHD の 発症頻度が高い。これは移植藏器の拒絶を防ぐために $\mathrm{T}$ 細胞機能を抑える免疫抑制剤が投与されるためと 考えられる.

$\mathrm{ABO}$ 不適合間の臟器移植では, 宿主に生着したド ナーB リンパ球は, もともとドナー体内で産生してい 
た抗 A または抗 B 抗体をつくるので, $\mathrm{ABO}$ 不適合に よる溶血が起きる ${ }^{3)}$. 外国における脳死ドナーからの 肝移植患者では，抗 A または抗 B 抗体の存在期間は, ばらつきが大きいが，中間值で示すと移植後 7 日で抗 体が検出され，20日で検出できなくなるとの報告があ る.機構は分からないが, 多くの症例では抗体は消失 する.

ドナーが妊娠や輸血によって抗 D のような不規則 抗体を産生している場合または特発性血小板減少性紫 斑病のように自己抗体を産生している場合には，移植 後も抗体を産生して溶血や血小板減少を来すことがあ

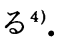

このように B cell-mediated GVHD の発症頻度が 高いが, 実質臟器移植に伴って致命的な T cell-mediated GVHD が発症することもある. 日本で行われてい る親子間の生体肝移植では輸血後 GVHD と同じ理由 で T cell-mediated GVHD の発症の危険が高い.

\section{5. 診断}

特徵ある臨床所見, 皮膚生検像, DNA 多形性による キメラの証明, 患者 HLA 型のドナー型への変化を指 標として診断する。DNA 多形性によるキメラの証明 は少量の検体で短時間にできること，爪 $\mathrm{DNA}$ を患者 自己の検体として使えることなど便利なので，利用さ れている. しかし, 問題は検出感度を上げると, 後述 のミクロキメラを検出する危険性があり, 検出感度を 下げると発症初期のキメラを検出できない恐れがあ る.

患者とドナーの HLA 型の判定は輸血後 GVHD 症 例の一部でしかなされていない. しかも以前の症例は クラス II 抗原の分析が不十分である.どのような HLA 型の組み合わせで発症し, 宿主のどの抗原が攻 撃の指標になっているのかを解析することは，発症機 構を理解するために重要である.

マウスを使った MHC の相違による GVHD の発症 研究では, クラス I とクラス II が異なる場合に急性 GVHD が発症し，クラスIIだけが異なる場合に慢性 GVHD が発症し，クラスIだけが異なる場合には GVHD は発症しないと言われている5)。これが人 GVHDに当てはまるのか明らかでない.

\section{6. 血液放射線照射の問題点}

昨年12月に輸血学会から血液放射線照射に関するガ イドラインIIIが出された ${ }^{11}$. その時点での適切なガイ ドラインであり，その後 5 カ月しか経っていないが, 現時点で考えて，問題点があるならば指摘すべきであ
ろう。照射線量は15〜 50Gy となっている. 15Gy また は20Gy の照射で免疫不全状態の患者に GVHD が発 症したとの報告があるので, 免疫不全状態の患者への 輸血では25〜 50Gy，または30〜 50Gy の照射が必要で はないか. 国立大学附属病院輸血部では約半数の施設 で20，25または30Gy から50Gy の範囲の照射を実施し ている.

外科手術患者では, 採血後 2 週間以内の血液で GVHD が起きているので，この期間の血液に照射する ことになっている．著者も現時点ではこれを支持する が，これが適切であるか，さらに見守りたい．赤血球 製剂の有効期限が21日なので，照射しないで 3 週間目 の血液を輸血しょうと思っても現実には入手しがた い,

照射による発癌やウイルス活性化の危険について は，照射初期から取り上げられて来た問題であるが, 現状の照射線量では発癌誘発効果よりも殺細胞効果が 高いと言われている。

リンパ球の放射線感受性は Tリンパ球を指標に検 討されて来た. $\mathrm{B}$ リンパ球は $\mathrm{T}$ リンパ球により感受性 が高いので安全である.一方, プライムド $\mathrm{T}$ リンパ球 は感受性が低いので，15Gy より高い照射が必要であ るとの意見がある ${ }^{6}$.

\section{7. キメラの多様性}

リンパ球のキメラ状態は初期に考えていたよりも， 多様性がある．前記の致命的 T cell-mediated GVHD および B cell-mediated GVHD の外に，前者の症状を 示したが救命された非定型的 GVHD 症例が報告され ている. 妊娠, 輸血, 臟器移植の後で, ミクロキメラ が成立することが報告されている.臟器移植の後では, ミクロキメラを経て免疫寛容が成立するとの説があ る.しかし，ミクロキメラは次第に減少するので，免 疫寛容の前提条件ではないとの説もある77. 臓器移植 が普及してくると，ミクロキメラの症例が増えて，こ の問題も次第に明らかになるであろう。

\section{文献}

1）日本輸血学会輸血後 GVHD 対策小委員会：輸血 によるGVHD 予防のための血液に対する放射線 照射ガイドラインIII．日輸血会誌，42(6)：1-9, 1996.

2) Nishimura, M., et al.: Identification of HLA class II antigens as the targets of effector clones which way cause transfusion-associated graftversus-host disease. Transfus. Med., 7: 89-94, 1997. 
3) Kunimasa, J., et al.: Hemolytic reaction due to graft versus host (GVH) antibody production after liver transplantation from living donors: Report of two cases. Surgery Today, 印刷中

4) Ramsey, G. : B-cell-mediated graft-versus-host disease in transplantation. Vox Sang., 70(Suppl. 3) : 74-77, 1996.

5）藤原道夫：GVHD の概念. 十字猛夫, 伊藤和彦
編，輸血後 GVHD，金芳堂，京都，1994，p. 118.

6）南 隆彦：輸血後 GVHD の予防, 第 5 回赤十字 血液シンポジウム一安全な輸血をめざして一. p. 101-105, 1997.

7) Schlitt, H.J.: Is microchimetism needed for allograft tolerance? Transplant. Proc., 29 : 8284, 1997. 